\title{
Diagnostics of Environmental Risks and Mapping of Surface Water Sensitivity Due to Metal Contamination from Artisanal Gold Mining in Côte d'Ivoire: Case of Angovia, Kokumbo, Hire and Agbaou
}

\author{
Akpo Kouakou Sylvain'1, Koné Tiangoua', Coulibaly Sandotin Lassina², \\ Mahamadou Kamagate ${ }^{2 *}$, Coulibaly Lacina ${ }^{1,2}$ \\ ${ }^{1}$ Laboratory of Environment and Aquatic Biology, University of Nangui Abrogoua, Abidjan, Côte d'Ivoire \\ ${ }^{2}$ Department of Chemistry, University of Man, Man, Côte d'Ivoire \\ Email: *mahamadou.kamagate@univ-na.ci
}

How to cite this paper: Sylvain, A. K., Tiangoua, K., Lassina, C. S., Kamagate, M., \& Lacina, C. (2020). Diagnostics of Environmental Risks and Mapping of Surface Water Sensitivity Due to Metal Contamination from Artisanal Gold Mining in Côte d'Ivoire: Case of Angovia, Kokumbo, Hire and Agbaou. Journal of Geoscience and Environment Protection, 8 , 47-64.

https://doi.org/10.4236/gep.2020.82004

Received: December 30, 2019

Accepted: February 2, 2020

Published: February 5, 2020

Copyright $\odot 2020$ by author(s) and Scientific Research Publishing Inc. This work is licensed under the Creative Commons Attribution International License (CC BY 4.0).

http://creativecommons.org/licenses/by/4.0/ (c) (i) Open Access

\begin{abstract}
The present study performed on the Angovia, Kokumbo, Hire and Agbaou sites consisted of mapping the environmental risks linked to artisanal gold mining activities in Côte d'Ivoire. An inventory was done by observing the different phases of gold extraction and identifying the risks associated with these phases. Using a Geographic Information System (GIS), the representation of the spatial distribution of the pollution risks has been realized from indicator descriptives of the environmental sensitivity (i.e. slope, proximity to the watercourse, soil cover) and the transfer indicator (i.e. rainfall). The analysis of this map showed low sensitivity of mercury ( $\mathrm{Hg}$ ), arsenic (As), copper $(\mathrm{Cu})$ and zinc $(\mathrm{Zn})$ measured in the waters of the Hire and Agbaou localities, while moderate sensitivity in Kokumbo surface waters and high sensitivity for those of Angovia locality were observed. Moreover, analysis of $\mathrm{Hg}, \mathrm{As}, \mathrm{Cu}$ and $\mathrm{Zn}$ content spatial distribution maps in surface waters revealed that $\mathrm{Hg}$ and As come mainly from the artisanal mining activities for most localities. Among these metallic trace elements observed, only the $\mathrm{Hg}$ content was above the WHO Limit Values, $1994\left(>0.001 \mathrm{mg} \cdot \mathrm{L}^{-1}\right)$. The continuous spread of metallic trace elements in surface water can pose serious health problems for people living around artisanal gold mining sites, hence the need to put in place a protection plan against contamination.
\end{abstract}

\section{Keywords}

Mapping, Environmental Risks, Artisanal Gold Mining, 
Geographic Information System

\section{Introduction}

Mining has become a major economic activity in several African countries and is an income source for many people while generating many hopes for development. However, it should be noted that the exploitation of mineral resources, by its non-renewable character, which may contradict the sustainable development concept (Jacques et al., 2005). The population engages in the clandestine mining of gold because of poverty and the firmness lack of decision-makers. Artisanal mining may seem like a lucrative business, given the great enthusiasm it generates, but it nevertheless has many negative impacts, both social and environmental (Goh, 2016). Several previous studies have reported risks to the environment and public health (Taylor et al., 2004; Ouedraogo, 2006; Andriamasinoro \& Angel, 2012).

According to Maradan et al. (2011), in Burkina Faso, the artisanal gold mining typically relies on the openings of trenches, wells, scraping and flipping, with the weakening of soils and the progressive destruction of land arable. In Mali, for example, lack of hygiene and exposure to dust and moisture in holes expose miners to all kinds of diseases.

Then, the use of chemicals (e.g., mercury, cyanide, hydrochloric and sulfuric acids) and other non-biodegradable solid wastes can reduce soil fertility and the quality of water resources (Wandan et al., 2015). Although these studies are important for combating water pollution and for sustainable soil management, the environmental pollution risks related to the flow of chemicals used in the extraction process are not clearly mentioned in previous studies.

Côte d'Ivoire, like other African countries, has enormous mineral potential that can be an important base for its economy. However, since the fall in the costs of agricultural commodities in the 1980s (Soro, 2011), the Ivorian government has wanted to make extractive industry the second pillar of its economy (Atsé, 2007). In 1990, mining activities thus boomed especially with the discovery of several gold deposits, some of which are currently in operation and are close to $0.7 \%$ of Gross Domestic Product (GDP) (Yapi et al., 2014). Indeed, artisanal gold mining in Côte d'Ivoire accounted for $20 \%$ to $30 \%$ of world production estimated at between 500 and 800 tonnes in 2005 (ONUDI, 2009). According to the data from the Ministry of Industry and Mines, the proliferation of gold panning sites affects 24 of the country's 31 regions with more than 500,000 people involved (Goh, 2016). The exploitation of gold is intensifying more and more and is attracting many people from all walks of life, but few works have been done on the environmental risks that could arise in the long term (Coulibaly et al., 2009; Sirven, 2006). It is therefore important to list all the areas hosting these illegal activities, to control and sensitize the local populations. To do 
this, the use of spatial and numerical information through mapping could be a decision-making tool in the management of environmental risks from mining operations (Kaminska et al., 2004; IFEN, 2012).

It is in this context that this study was initiated in order to fill the lack of scientific information and to draw the attention of decision-makers and the population to the dangers that artisanal gold mining activities may have on the environment. Specifically, it aimed to 1) carry out a diagnosis of the environmental risks associated with the artisanal gold mining activities sites studied; 2) develop the sensitivity map of the surface waters near of the study area to pollution; and 3) establish the spatial distribution of metallic trace elements concentrations from surface waters.

\section{Study Areas}

This study focused on Hire, Kokumbo, Agbaou, and Angovia villages (Figure 1), located in southern Côte d'Ivoire between 659,194.069 - 791,709.78 m North latitudes and 207,777.30 - 269,001.59 m Eastern longitudes (UTM 30). Indeed, Hire and Agbaou localities belong to the equatorial transition regime (Attiean climate) characterized by two dry and two rainy seasons. Besides, the rainfall varies from $246.15 \mathrm{~mm}$ in June (i.e., during the major rainy season) to $29.8 \mathrm{~mm}$ in January (i.e., for the major dry season) with an annual rainfall of about 1300 $\mathrm{mm}$, and high humidity of $80 \%$ to $90 \%$ (Endeavour Mining Corporation, 2015).

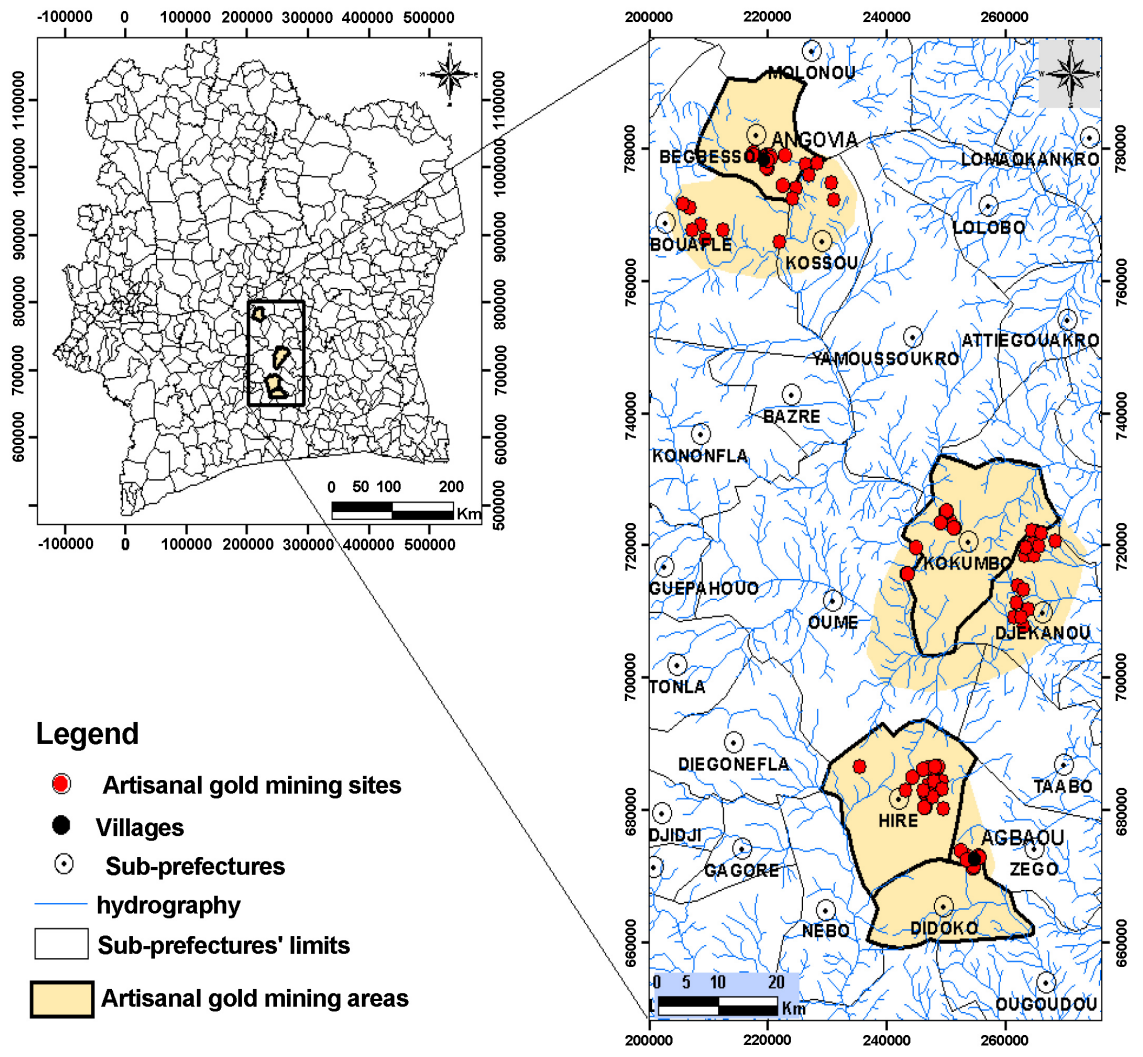

Figure 1. Presentation of different study areas. 
Agbaou and Hiré geology are based on rocks of the Oume-Fetekro greenstone belt, composed mainly of deformed mafic-volcanic and metamorphosed into greenschist facies. The greenstone belt is folded into an antiform and the Agbaou deposit is located near the hinge of the fold, on the Eastern limb. The dominant vein-set is oriented along the strike of the fold (i.e. roughly northeast/southwest) and dip to the southeast, at a moderate to steep attitude (Eisenlohr, 1998). On the other hand, Kokumbo is characterized by a humid tropical transition climate obtained by the combination of the equatorial humid climate in the south and the humid tropical climate in the north, having mean annual rainfall ranging from 1000 to $1400 \mathrm{~mm}$ with an average temperature of $30^{\circ} \mathrm{C}$ (Brou, 2005). It worth noting that Kokumbo experiences two dry seasons and two rainy seasons with a moisture content of $60 \%$ to $70 \%$, whereas Angovia climate is Baoulian type, with two greater seasons (i.e. a major rainy season from March to June, and a major dry season from December to February), alternated by two small ones (i.e. a small rainy season from July to August, and a small dry season from September to November). Otherwise, the average rainfall of Angovia varies between 1000 and $1600 \mathrm{~mm}$ (Goula et al., 2007). Structural analysis of Côte d'Ivoire revealed an important hidden cross structure in the Kokumbo area, covered with wooded hills and extensive lateritic cover. The rocks are also invaded by granites that appear to have been a focus for gold hydrothermal fluids and hence the formation of higher grade gold mineralization. Finally, Kokumbo contains gold mineralization of quartz veins in several vein orientations. These host rocks include mafic volcanic rocks, black shale, and granite, favoring gold prospecting (Predictive Discovery Limited, 2014). In the region of Yaoure, including Angovia, on the meeting of the birrimian formations which are of the eburnian cycle (Coulibaly et al., 2008), the outcrops consist mainly of metagabbro, amphibolite, granodiorite, meta-arenite and shale (Fabre et al., 1990; Fabre \& Morel, 1993; Feybesse, 2001). The southern part of Côte d'Ivoire to which these different localities belong is generally composed of three types of soils, namely a ferrallitic soil (ferralsols), a hydromorphic soil (gleysols) and a brown soil (Cambisols) (Dabin et al., 1960; Atsé, 2007).

\section{Material and Methods}

\subsection{Cartographic Data}

By using a digital camera for shooting, and a Garmin ETREX 30 GPS receiver for determining the geographical coordinates of artisanal gold mining points, several data were collected to map. The cartographic data consists mainly of maps in digital format of the Côte d'Ivoire geology, and also for the realization of the hydrographic network map of the zones, a file of type "vector" representing the Ivorian hydrographic network has been used. Then, the 1/2,000,000 geological map and the mining cadaster map of the South-East, East and North-East Côte d'Ivoire areas at 1/1,000,000, established by Tagini et al. (1972) and published by Mining Development Company, served to highlight the geological 
units (i.e. nature of the geological formation) and the map of gold mining sites encountered within the different zones of the study area, respectively.

Concerning topography, the $30 \mathrm{~m}$ resolution Shuttle Radar Topography Mission (SRTM) image was uploaded via https://earthexplorer.usgs.gov/ covering the study areas, as well as the 2011 data of Côte d'Ivoire administrative limit map provided by the National Committee on Teledetection and Geographic Information (NCTGI) were also used.

\subsection{Diagnostic of Environmental Risks Associated with Gold Mining Activities}

During the study areas' investigations, an inventory basis on observations has been performed. It was: 1) to observe the different phases of gold extraction: these phases range from sinking to mercury washing of the soil and during these stages, there is first the digging of the soil which consists of making circular or rectangular holes with an average depth of about $25 \mathrm{~m}$. Then, the stages of crushing and grinding, which make it possible to reduce the size of the particles and make them into powder in order to facilitate the recovery of the gold by washing. The second stage: 2) the general layout of the gold extraction site: it involved observing the layout of the sites and the third stage was: 3 ) the list of the various environmental risks of the gold extraction sites: it is the aim to list the various risks, namely contamination of the soil and sediments, surface water, deforestation, excavation of the soil.

\subsection{Development of Surface Water Sensitivity Map to Chemicals from Artisanal Gold Mining Zone}

In order to exploit and analyze the datas obtained from the study areas' investigations, all data were processed using QGIS 2.12 and ArcGIS 10 softwares, from which all the established maps have been georeferenced in the WGS 84 UTM coordinate system, zone 30 , northern hemisphere. With a spatial multi-criteria analysis of the sensitivity of the aquatic environments, all the layers of the simple indicator entities were rasterized in GRID format by defining a common resolution cell size of $30 \mathrm{~m}$ using the functions "Entities towards Rasters". The "Reclassification" allows having the classes and codes envisaged. Surface water sensitivity ratings range from 1 (i.e., low) to 4 (i.e., very high) (see Table 1). Combinations were done in "Raster" mode using the "Raster Calculator" tool (Module weighted sum and multiplication) of the "Spatial Analyst" module of ArcGIS according to Equation (1).

$$
S_{m a}=\left[\alpha+d_{h}+P_{e d o}\right] \times\left[G c \times P_{l u}\right]
$$

with:

$S_{m a}$ Sensitivity of the aquatic environment;

$\alpha$ : Slope;

$d_{h}$ : Proximity distance to the hydrographic network;

$P_{e d o}$ Pedology;

Gc. Ground cover;

$P_{l u:}$ Pluviometry. 
Table 1. Slope type codification $(\alpha)$ versus slope classes.

\begin{tabular}{ccc}
\hline Slope classes $\boldsymbol{\alpha}(\%)$ & Slope type & Codes \\
\hline 0 & Very low & 1 \\
$0-1$ & Low & 2 \\
$1-5$ & Average & 3 \\
$>5$ & High & 4 \\
\hline
\end{tabular}

The indicator parameters in Equation (1) are described as follows:

\section{- Slope indicator $(\alpha)$}

An ASTGTM 2 Digital Image Elevation Model (DEM) with a 30-meter resolution covering the study area was used for the determination of altitudes and slope thresholds. Then, a code from 1 to 4 was assigned to each grade of the slope. According to Farr \& Kobrick (2000), and Slater et al. (2006), slope types can vary from very low to high depending on thresholds (see Table 1).

\section{- Distance indicator $(\mathrm{dh})$}

The distance indicator map ( $\mathrm{dh}$ ) to the watercourse was done basis on the river system of the previously determined study area. This distance, which reflects the proximity of artisanal gold mining zones to the river system, was calculated using the "Euclidean Distance" function of the Spatial Analyst extension of the ArcGIS software. To further understand, a code was assigned to each distance obtained between the artisanal gold mining sites and hydrographic network, ranging from 1 (low) to 4 (very high) (Macary et al., 2007), thereby showing the exposure risk versus the distances (Table 2).

Table 2. Contamination risk codification versus distance to the river system.

\begin{tabular}{ccc}
\hline Distance to the river system $(\mathrm{m})$ & Contamination risk & Codes \\
\hline $0-1000$ & Very high & 4 \\
$1000-3000$ & High & 3 \\
$3000-5000$ & Average & 2 \\
$>5000$ & Low & 1 \\
\hline
\end{tabular}

\section{- Pedology indicator (Pedo)}

This indicator was determined from the pedological sketch of Côte d'Ivoire at 1/200,000 of Perraud (1979), by digitizing and georeferencing it in order to obtain the pedological map of the study area. Then, soil types were codified according to their ability to transfer pollutants into surface water (see Table 3). As shown in Table 3, weakly desaturated ferrallitic soils with induration (i.e., code 4) are the most vulnerable to pollutant transfer, followed by indurated moderately desaturated ferrallitic soils (i.e., code 3 ) and moderately desaturated ferrallitic soils remained weakly indurated and impoverished (i.e., code 2), finally, ferrallitic soils moderately desaturated reworked and depleted designated by code 1 . 
Table 3. Indicator pedology codification versus soil types.

\begin{tabular}{lcc}
\hline \multicolumn{1}{c}{ Soil types } & Vulnerability & Codes \\
\hline $\begin{array}{l}\text { Ferrallitic soils moderately desaturated reworked and depleted } \\
\begin{array}{l}\text { Moderately desaturated ferrallitic soils remained weakly } \\
\text { indurated and impoverished }\end{array}\end{array}$ & Low & 1 \\
$\begin{array}{l}\text { Indurated moderately desaturated ferrallitic soils } \\
\text { Weakly desaturated ferrallitic soils with induration }\end{array}$ & High & 3 \\
\hline
\end{tabular}

\section{- Ground cover (Gc)}

The ground cover $(\mathrm{Cv})$ representing the factor map was developed using the vegetation vector layers of 1979 in Côte d'Ivoire. This layer has been updated by the zonation footprint of the sites' gold mining of the different study areas. The factor is defined as the ratio of bare soil loss under specific conditions to soil loss corresponding to soils under an agricultural system (El Garouani et al., 2008). Indeed, the plant cover protects the soil, ensures the damping of raindrops, the slowing down of runoff and infiltration. Thus, for low vegetation, soil loss decreases with increasing vegetation cover (Soutter et al., 2007). Here, Table 4 exhibits different codifications for the influence of soil occupancy on the runoff.

Table 4. Runoff coefficient codification versus soil occupancy types.

\begin{tabular}{cccc}
\hline Soil occupancy types & \multicolumn{2}{c}{ Runoff coefficient } & Codes \\
\hline Bare soil & 1 & Very high & 4 \\
Mesophilic savannah & 0.7 & High & 3 \\
Degraded forest & 0.6 & Average & 2 \\
Dense forest & 0.001 & Low & 1 \\
\hline
\end{tabular}

\section{- Pluviometry indicator $(\mathrm{Plu})$}

The study zones' investigations allowed us to identify the use periods (i.e., March to November) of chemicals in gold ores. In fact, these periods concurring to the rainy season, denote workout risks of these products in the surface waters. Four (4) average rainfall classes were defined by the Jenks method, 1977 in Antoni et al., 2012, according to the calculated rainfall intensity intervals. Finally, a code from 1 to 4 has been assigned to these classes in order to indicate the pollutant entrainment risk level (see Table 5).

Table 5. Workout risk codification versus pluviometry.

\begin{tabular}{ccc}
\hline Pluviometry average $(\mathrm{mm})$ & Entrainment risk & Codes \\
\hline $1200-1300$ & Low & 1 \\
$1300-1400$ & Average & 2 \\
$1400-1500$ & High & 3 \\
$>1500$ & Very high & 4 \\
\hline
\end{tabular}




\subsection{Spatialization of Metallic Trace Element Contents of Surface Waters Near the Artisanal Gold Mining Sites}

The analysis of metallic trace element concentrations (i.e., $\mathrm{Hg}, \mathrm{Cu}, \mathrm{Zn}, \mathrm{As}$ ) was performed at the National Laboratory for Agricultural Development and then spatialized. The spatialization consisted in mapping the average concentration of metallic trace elements obtained according to the different localities of Angovia, Kokumbo, Hiré et Agbaou. Indeed, four (4) concentration intervals were defined for each metal, ranging from low to very high, to show their level risk of contamination (see Table 6).

Table 6. Risk level versus average concentration of metallic trace elements within surface water (Yapi et al., 2014).

\begin{tabular}{|c|c|c|c|}
\hline \multicolumn{2}{|c|}{ Average concentration $\left(\mathrm{mg} \cdot \mathrm{L}^{-1}\right)$} & \multirow{2}{*}{$\begin{array}{c}\text { Contamination risk } \\
\text { Low }\end{array}$} & \multirow{2}{*}{ WHO Limit Values, $1994\left(\mathrm{mg} \cdot \mathrm{L}^{-1}\right)$} \\
\hline \multirow{4}{*}{ Mercury (Hg) } & $<0.00033$ & & \\
\hline & $0.00034-0.00066$ & Moderate & \\
\hline & $0.00067-0.001$ & High & 0.001 \\
\hline & $>0.001$ & Very high & \\
\hline \multirow{4}{*}{ Arsenic (As) } & $<0.0033$ & Low & \\
\hline & $0.0034-0.0066$ & Moderate & 0.01 \\
\hline & $0.0067-0.001$ & High & \\
\hline & $>0.01$ & Very high & \\
\hline \multirow{4}{*}{ Copper $(\mathrm{Cu})$} & $<0.66$ & Low & \\
\hline & $0.67-1.66$ & Moderate & 2.00 \\
\hline & $1.67-2$ & High & \\
\hline & $>2$ & Very high & \\
\hline \multirow{5}{*}{ Zinc (Zn) } & $<1$ & Low & \\
\hline & $1-2$ & Moderate & 3.00 \\
\hline & & & \\
\hline & $1-3$ & High & \\
\hline & $>3$ & Very high & \\
\hline
\end{tabular}

\section{Results and Discussion}

\subsection{Environmental Risks Related to Artisanal Gold Mining Sites}

The activity of artisanal gold mine has destroyed of the vegetal layer and the soil through ditches more or less gaping left abandoned (see Figure 2(a)), siltation of rivers and vein wells (see Figure 2(b)), and dust emission, discharge of waste oil and washing of crushed rock (see Figure $2(\mathrm{c})$ ). Hence, the soil is irreversibly degraded because it cannot be restored after the abandonment of the sites, disrupting the ecological balance. 


\section{(a)}

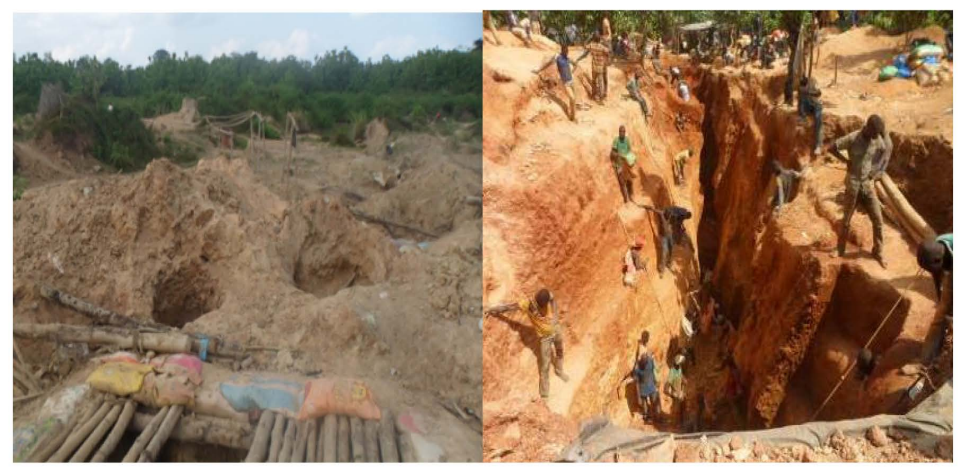

(b)

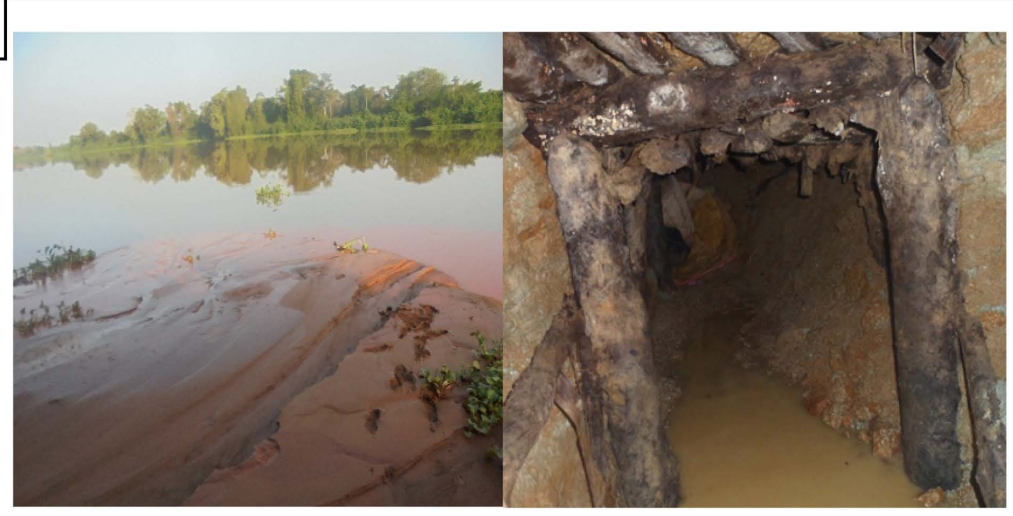

(c)
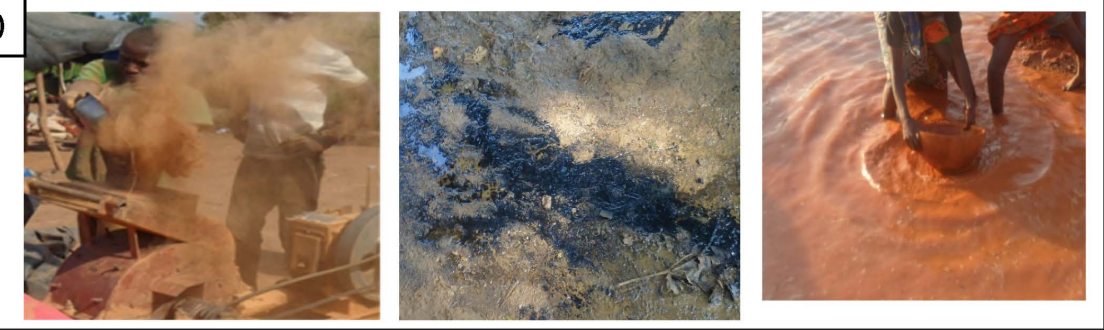

Figure 2. Environmental risks observed on the sites: pit and channel openings (a), river siltation and vein (b) wells and dust emission, discharge of waste oil and washing of crushed rocks (c).

Otherwise, the storage of barren ores causes near-rivers siltation following heavy runoff during the rainy season and the risk of soil erosion, as well as the depths of vein sinks increase (greater than or equal to $40 \mathrm{~m}$ ) that pose risks of groundwater pollution (Figure 2(b)). The same observations have also been observed on artisanal gold mining sites in different neighboring countries such as Mali and Burkina Faso (Diallo et al., 2007; Hien, 2012; Roamba, 2014). Crushing and grinding of rocks containing gold by motorized machinery have also been observed, which could lead to noise pollution and health problems such as lung diseases due to dust, as well as soil pollution by spilling hydrocarbons from the rudimentary machines used (Figure $2(\mathrm{c})$ ). These impacts result in the modification of stream ecology and the loss of aquatic fauna sensitive to these disturbances. 
It worth noted that they use rudimentary equipment and did not have the personal protective equipment that could protect them from inhaling dust and the injuries. Kéita (2001) was able to identify among the miners' pathologies such as musculoskeletal disorders, sleep and respiratory disorders.

\subsection{Water Surface Sensitivity of Study Areas to Chemical Pollution from Artisanal Gold Mining Activities}

Figure 3 represents the mapping of the sensitivity of surface water to metallic trace elements. Indeed, the analysis of this map showed a low sensitivity for all of the metallic trace elements (i.e., $\mathrm{Hg}, \mathrm{As}, \mathrm{Cu}$ and $\mathrm{Zn}$ ) measured in the waters of the Hire and Agbaou localities, a moderate sensitivity in Kokumbo surface waters and a high sensitivity for the only locality of Angovia. This high Angovia water sensitivity is due to the strong gold mining activities, the topographic and geological, as well as the climatic conditions above-explained in this area.

Indeed, this locality has a steep slope (slope $>5 \%$ ) and a relatively high rainfall (between 1000 and $1600 \mathrm{~mm}$ ) which would favor the transport of the loose fractions of mounds of sterile land stored near the wells towards the watercourse causing their siltation, leading to the increased risk of transfer of pollutants to these rivers (Yapi et al., 2014; Ouedraogo, 2006). It worth noted that these sludges contain heavy metals resulting from gold recovery processes.

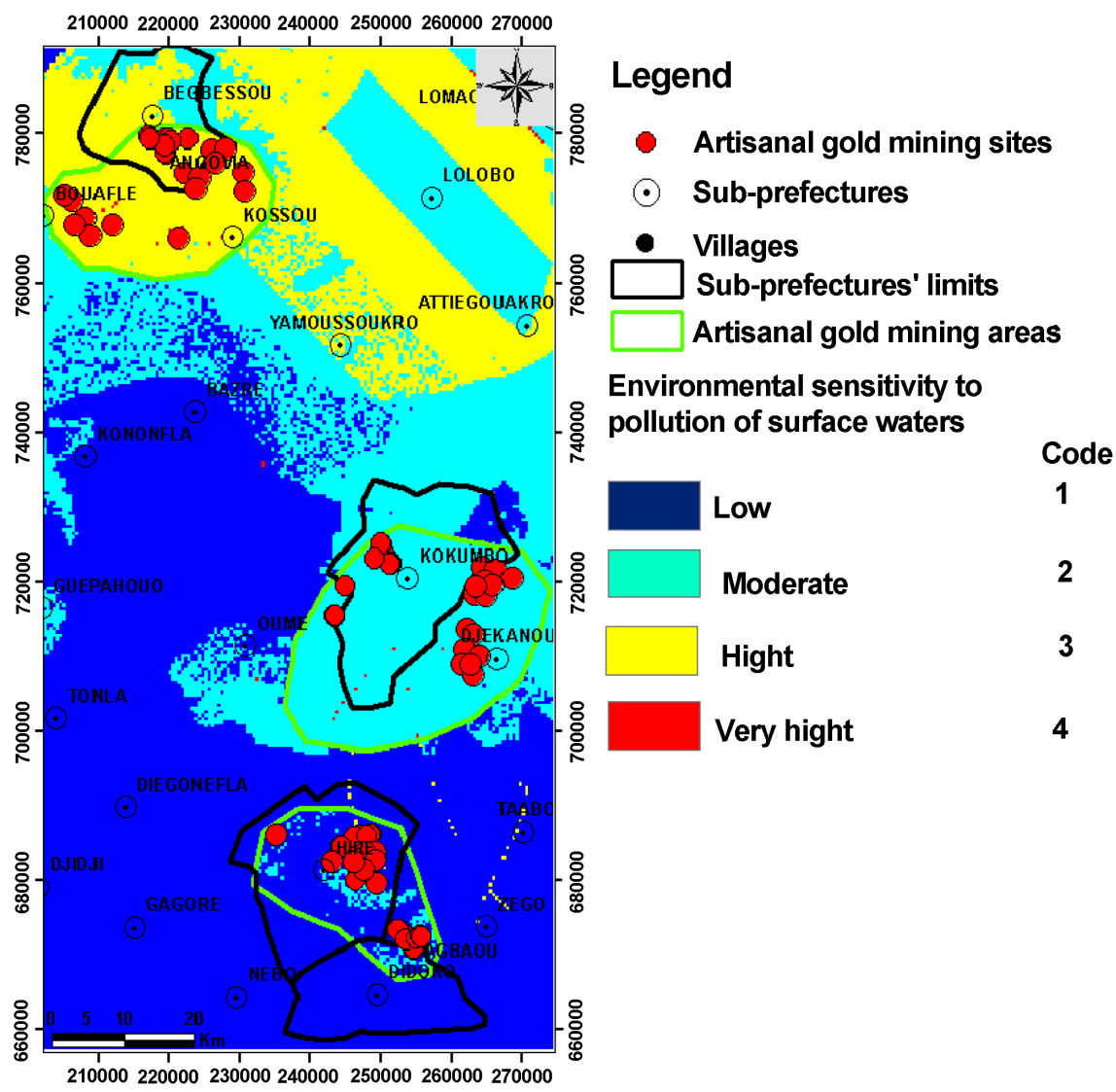

Figure 3. Surface water sensitivity map. 


\subsection{Spatial Distribution of Metallic Trace Element Concentrations from Surface Water near Artisanal Gold Mining Sites}

\subsubsection{Spatial Distribution of Mercury Concentrations}

The analysis of the spatial distribution map of the average concentration of mercury $(\mathrm{Hg})$ is presented in Figure 4. Indeed, mercury concentration in the surface water is very high at all sampling sites $\left(>0.001 \mathrm{mg} \cdot \mathrm{L}^{-1}\right.$; WHO Limit Values, 1994). These high concentrations could be due to the fact that this product is widely used by miners in the final process of gold mining in an uncontrolled way (Telmer \& Veiga, 2009). Studies previously carried out in some of these areas investigated as in the commune of Hire revealed that the source of mercury in the surface waters of this locality would be exclusively due to gold washing activity (Koffi, 2015). Once in the environment, mercury can undergo several complex processes of transport and transformation depending on its different chemical forms and environmental conditions (Liu et al., 2012). However, despite these transformations, it is important to understand that mercury remains persistent in the environment because it is unlikely to be broken down or degraded. Mercury can pass through different states and species during its cycle, but within its simplest form (i.e., elemental mercury), it remains harmful to humans and the environment and, once circulated in the biosphere, it will not be eliminated by natural processes (PNUE, 2012).

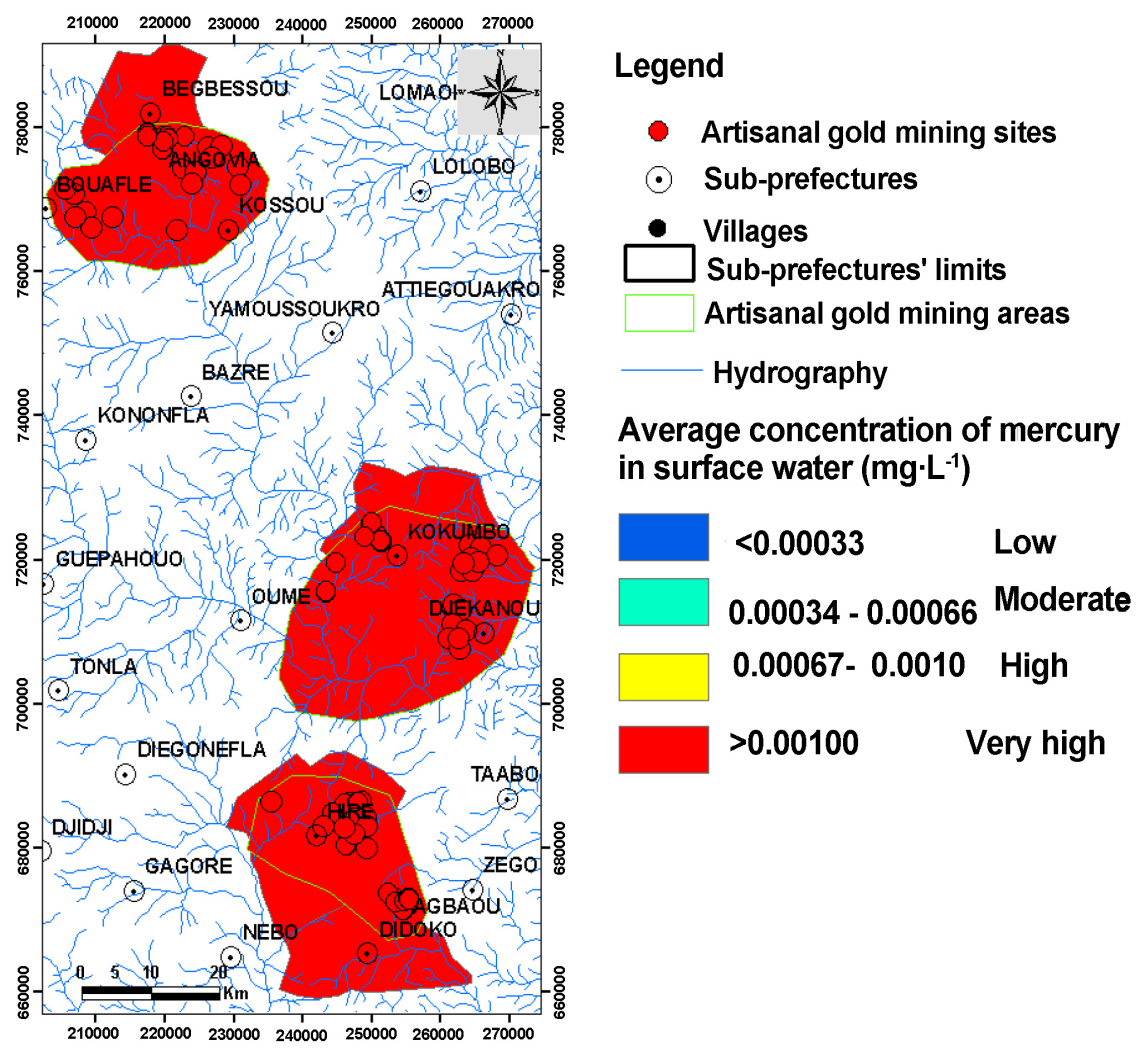

Figure 4. Spatial distribution map of mercury. 


\subsubsection{Spatial Distribution of Arsenic Concentrations}

The spatial distribution of arsenic concentrations in surface water was exhibited in Figure 5. Indeed, high concentrations (i.e., $0.0067-0.001 \mathrm{mg} \cdot \mathrm{L}^{-1}$ ), but below at WHO Limit Values, 1994, were observed within Hire and Angovia localities, whereas those of Agbaou and Kokoumbo were moderates (i.e., $0.0034-0.0066$ $\mathrm{mg} \cdot \mathrm{L}^{-1}$ ) (Figure 5). This high amount of arsenic in Hire and Angovia would come from slag heaps and associated gold smelters observed on these sites, which are rich in arsenopyrite (FeAsS). Arsenopyrite is the main complexing mineral of arsenic. It is found in very varied deposits because it is related to metals that one seeks to exploit (e.g. gold). Although arsenopyrite is much more widespread than gold, an almost systematic association of arsenopyrite with gold was established in the 1960s, to the extent that this mineral eventually became a marker of gold deposits (Laperche et al., 2003; Bonnemaison, 2005). When the crude ore containing the metal bonded arsenopyrite is raised to the surface, it is then milled to a fine powder (between 50 and $150 \mu \mathrm{m}$ ) followed by washing to separate the metal from the arsenopyrite. Then the metal is of course recovered, but not the residue. As a result, there is an increased presence of arsenic in surface waters.

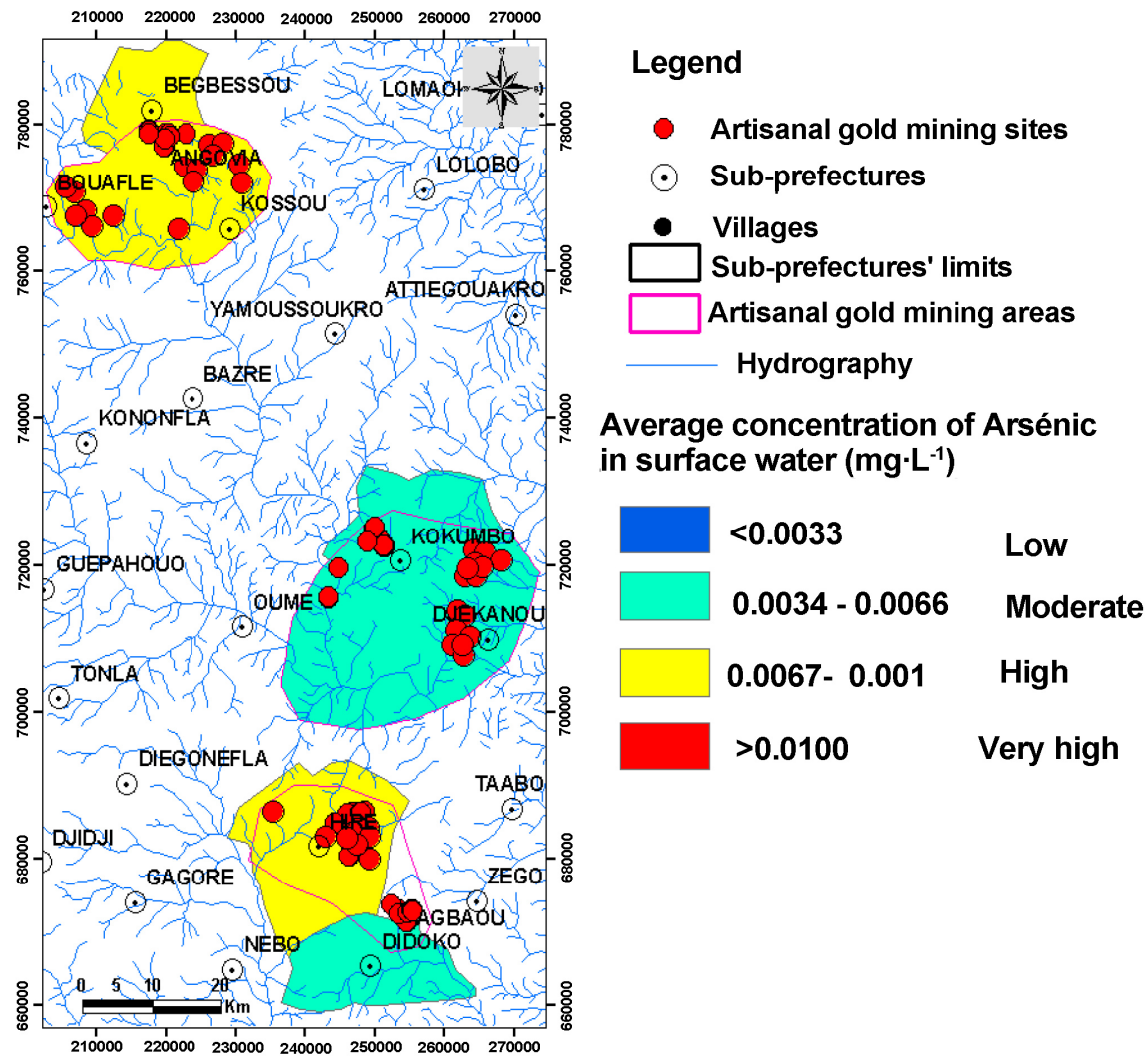

Figure 5. Spatial distribution map of arsenic.

\subsubsection{Spatial Distribution of Copper Concentrations}

Figure 6 shows the spatial distribution of average copper concentrations in surface water at different gold mining sites. Indeed, moderate concentrations (i.e., 
0.67 - $1.66 \mathrm{mg} \cdot \mathrm{L}^{-1}$ ) were obtained in the localities of Hire, Angovia, and Kokumbo, while those of Abgaou (i.e., $<0.66 \mathrm{mg} \cdot \mathrm{L}^{-1}$ ) are low (Figure 6). It should be noted that the exploitation of gold in these zones does not require the use of copper, so its presence does not come from the gold mining activity, but from the alteration and the disintegration of the rocks (mechanical erosion) whose minerals are rich in copper. That induces enrichment of surface water in copper

(Elazhari, 2013).

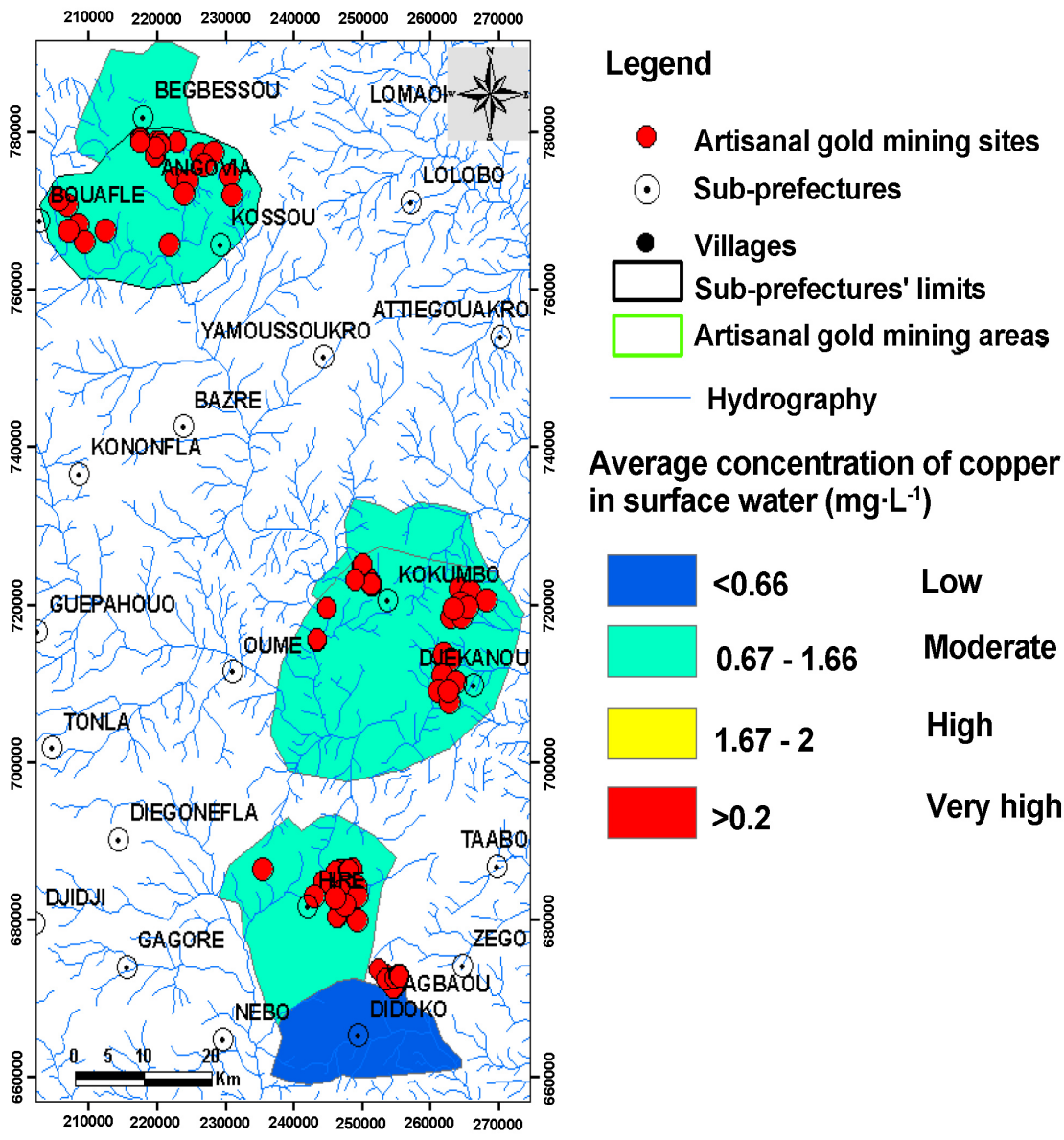

Figure 6. Spatial distribution map of copper.

\subsubsection{Spatial Distribution of Zinc Concentrations}

The spatial distribution of zinc in the surface waters of these different localities is shown in Figure 7. Overall, there are 2 levels of Zinc concentration in the surface waters of the area. Moderate concentrations were observed in Hire (i.e., 1 to $2 \mathrm{mg} \cdot \mathrm{L}^{-1}$ ), like those obtained in the localities of Angovia, Kokumbo and Agbaou are less than $1 \mathrm{mg} \cdot \mathrm{L}^{-1}$ (Figure 7). The high zinc content at Hire, unlike other localities, may be due not only to the presence in its soil of $\mathrm{Zn}$ ores such as blende $(\mathrm{ZnS})$ which are closely associated with gold ores, but also the use of zinc chips for the cementation of gold. Chips are often dumped at mine sites, which flow after raining into surface water (Ibrahim et al., 2019). 


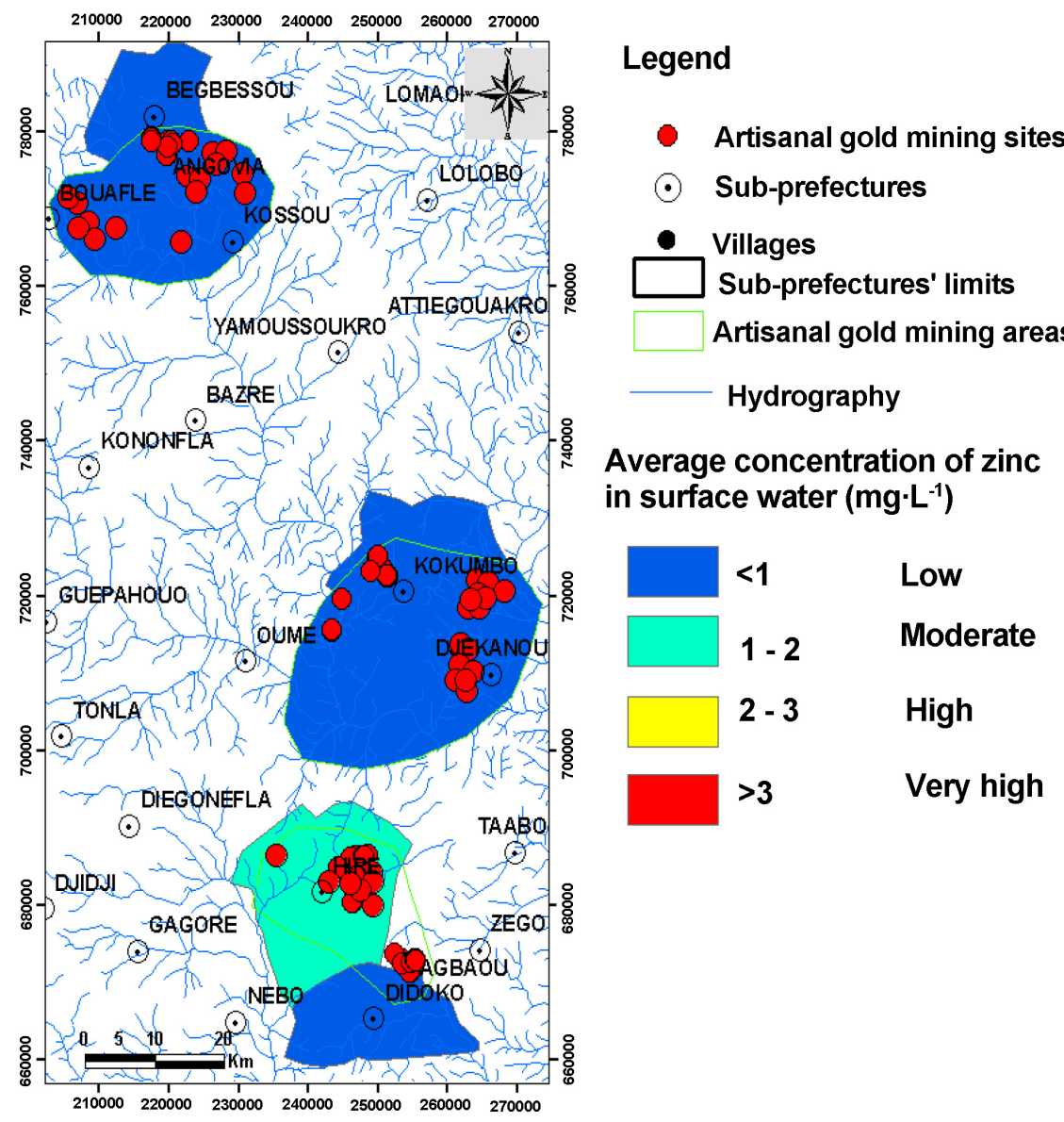

Figure 7. Spatial distribution map of zinc.

\section{Conclusion}

In this study, the spatial distribution and sensitivity of surface waters near gold mining sites were investigated. Environmental analysis beforehand of different artisanal gold mining sites showed that the activity of artisanal gold mine has destroyed the vegetal layer and the soil, siltation of rivers and vein wells, discharge of waste oil and washing of crushed rock, thus disrupting the ecological balance.

The analysis of this map showed low sensitivity for all of the metallic trace elements (i.e., $\mathrm{Hg}, \mathrm{As}, \mathrm{Cu}$ and $\mathrm{Zn}$ ) measured in the waters of the Hire and $\mathrm{Ag}$ baou localities, a moderate sensitivity in Kokumbo surface waters and a high sensitivity for the only locality of Angovia.

Moreover, analysis of metallic trace element concentrations spatial distribution maps revealed that mercury $(\mathrm{Hg})$ and arsenic (As) come mainly from the activities of artisanal mining on the water resources of most localities. Among the metallic trace elements observed, only the mercury content spent the WHO Limit Values, $1994\left(>0.001 \mathrm{mg} \cdot \mathrm{L}^{-1}\right)$.

This accumulation of metallic trace elements in the soil and their presence in surface water can pose serious health problems for the population living around 
the artisanal gold mining zone, thus requiring the establishment of a protection plan against contamination. However, a preliminary study of ETMs in sediments and in the vicinity of gold panning sites should be carried out to better understand the origin of the increase in ETMs. Concerning the rest of the research, an epidemiological study and an inventory of the diseases detected in the gold panners and in the inhabitants of the villages are in progress, as well as the content of the ETMs in the fish present in the surface waters of the villages.

\section{Acknowledgements}

We gratefully acknowledge the Sida-UNESCO and Minister in charge of Mines for providing Financial support and for data, permission to access and sampling, respectively. We also thank the Sanitation and Environmental Engineering research team members for their help during the field data collecting.

\section{Conflicts of Interest}

The authors do not declare any conflict of interest with respect to the publication of this article.

\section{References}

Andriamasinoro, F., \& Angel, J. M. (2012). Artisanal and Small-Scale Gold Mining in Burkina Faso: Suggestion of Multi-Agent Methodology as a Complementary Support in Elaborating a Policy. Resources Policy, 37, 385-396. https://doi.org/10.1016/j.resourpol.2012.04.004

Antoni, J. P., Klein, O., \& Moisy, S. (2012). Temporal Discretization. A Data Structuring Method for Dynamic Mapping (pp. 27-31). Paris: Maps \& Geomatics, French Committee for Cartography. https://hal.archives-ouvertes.fr/hal-00736467

Atsé, A. R. M. (2007). Environmental Study of the Gold Bonikro Project in Cote d'Ivoire (8 p.). Data Sheet Moged, Quebec: Institute of Energy and the Environment of the Francophonie.

Bonnemaison, M. (2005). Water, a Release Factor for Natural Arsenic. Geosciences, 2, 54-59.

Brou, Y. (2005). Climate, Socio-Economic Changes and Landscapes in Côte d'Ivoire. Summary of Scientific Activities Presented with a View to Obtaining the Habilitation to Direct Research (212 p.). Lille: University of Sciences and Technologies of Lille.

Coulibaly, A. S., Monde, S., Wognin, V. A., \& Aka, K. (2009). Analysis of Traces Metallic Elements (ETM) in the Estuarine Bays of Abidjan in Cote d'Ivoire. Afrique Science, 5, 77-96.

Coulibaly, Y., Boiron, M. C., Cathelineau, M., \& Kouamelan, A. N. (2008). Fluid Immiscibility and Gold Deposition in the Birimian Quartz Veins of the Angovia Deposit (Yaoure, Ivory Coast). Journal of African Earth Sciences, 50, 234-254. https://doi.org/10.1016/j.jafrearsci.2007.09.014

Dabin, B., Leneuf, N., \& Riou, G. (1960). Explanatory Note for the Soil Map of Côte d'Ivoire (39 p.). Adiopodoumé: State Secretariat for Agriculture.

Diallo, A., Wade, F., \& Kourouma, S. (2007). Effects of Artisanal Gold Mining on Forest Resources in Siguiri (32 p.). Conakry: University of Conakry, Guinea, Higher Agronomic and Veterinary Institute Valéry Giscard d'Estaing. 
Eisenlohr, B. (1998). Agbaou Gold Project, Geology and Mineralisation. 3-D Geological Services Pty Ltd., Goldivoire Internal Report.

El Garouani, A., Chen, H., Lewis, L., Triback, A., \& Abahrour, M. (2008). Mapping of Land Use and Net Erosion from Satellite Images and IDRISI GIS in North-East Morocco. Remote Sensing, 8, 193-201.

http://www.teledetection.net/upload/Teledetection/pdf/Vol8No3_193_201.pdf

Elazhari. (2013). Study of the Contamination by Metallic Trace Elements of the Sediments of Oued Moulouya and the Reservoir of the Hassan II Dam Downstream from the Abandoned Zeïda Mine, Haute Moulouya (115 p.). Master Thesis, Marrakesh: Cadi Ayyad University.

Endeavour Mining Corporation (2015). Technical Report Mineral Resource and Reserve Update for the Agbaou Gold Mine Côte d'Ivoire, West Africa (129 p.).

Fabre, R., \& Morel, B. (1993). Stratigraphy of the Birimian Units in the Center of the Ivory Coast (West Africa). Bulletin of the Geological Society of France, 164, 609-621.

Fabre, R., Ledru, P., \& Milési, J. P. (1990). The Lower Proterozoic (Birimian) of the Center of the Ivory Coast, Tectonic Evolution and Correlations (pp. 971-976). Report of the Academy of Sciences, France, Series II 311.

Farr, T. G., \& Kobrick, M. (2000). Shuttle Radar Topography Mission Produces a Wealth of Data. Eos Transactions American Geophysical Union, 81, 583-585. https://doi.org/10.1029/EO081i048p00583

Feybesse, J. L. (2001). Geometry and Kinematics of the Fractures Controlling the Placement of the Quartz Veins and Veinlets at the Angovia Mine (Yaouré, Côte d'Ivoire). Report BRGM/RC-50934-FR, 27.

Goh, D. (2016). Artisanal Gold Mining in Côte d'Ivoire: The Persistence of Illegal Activity. European Scientific Journal, 12, 18-36.

Goula, B. T. A., Konan, B., Brou, Y. T., Savane, I., Fadika, V., \& Srohourou, B. (2007). Estimation of Exceptional Daily Rains in Tropical Zones: Case of the Ivory Coast by Comparison of the Normal and Gumbel Log Laws. Hydrology Science Journal, 52, 49-67. https://doi.org/10.1623/hysj.52.1.49

Hien, K. (2012). Realization of an Environmental Diagnostic to Improve the Environmental Performance of Gold Panning in Burkina Faso: The Case of the Kampti Site (83 p.). Master Thesis, Ouagadougou: Urban Environment, International Institute of Water and Environmental Engineering.

Ibrahim, O. Z., Tankaridan-Badjo, A., Guero, Y., Maissoro Malam Idi, F., Feidt, C., Sterckeman, T., \& Echevarria, G. (2019). Spatial Distribution of Metallic Trace Elements in the Soils of the Komabangou Gold Zone in Niger. International Journal of Biological and Chemical Science, 13, 557-573. https://doi.org/10.4314/ijbcs.v13i1.43

IFEN (2012). Impact of Agricultural Practices on Transfers of Phytosanitary Products in Waters (36 p.). 2007 Data, France.

Jacques, E., Orru, J. F., \& Pelon, R. (2005). Sustainable Development: What Place for the Artisanal Mine. Geoscience, 1, 67-70.

Kaminska, I. A., Oldak, A., \& Turski, W. A. (2004). Geographical Information System as a Tool for Monitoring and Analyzing Pesticide Pollution and Its Impact on Public Health. Annale Agriculture Environment Medicine, 11, 181-184.

Kéita, S. (2001). Study on Artisanal Mines and Small-Scale Mining in Mali (No. 80, 54 p.).

Koffi, D. (2015). Impact of Artisanal Gold Mining on Surface Water at Hiré (Côte d'Ivoire) (73 p.). Master Thesis, Abidjan: Nangui Abrogoua University.

Laperche, V., Bodénan, F., Dictor, M.-C., \& Baranger, P. (2003). Methodological Guide to Ar- 
senic Applied to the Management of Polluted Sites and Soils (91 p.). BRGM/RP-52066-FR.

Liu, G., Cai, Y., O’Driscoll, N., Feng, X., \& Jiang, G. (2012). Overview of Mercury in the Environment. In G. Liu, Y. Cai, \& N. O’Driscoll (Eds.), Environmental Chemistry and Toxicology of Mercury (Ch. 1, pp. 1-12). Hoboken, NJ: Wiley Publication. https://doi.org/10.1002/9781118146644.ch1

Macary, F., Balestrat, M., Puech, C., \& Saudubray, F. (2007). Method for Estimating a Potential Spatialized Risk of Contamination of Surface Water by Agricultural Inputs on Different Spatial Scales: Application on the Slopes of Gascogne. In M. Batton-Hubert, T. Joliveau, \& S. Lardon (Eds.), SAGEO, Geomatiqueinternationales Meeting et Territory (pp. 1-20).

Maradan, D., Ouedraogo, B., Thiombiano, N., Thiombiano, T., \& Zein, K. (2011). Economic Analysis of the Mining Sector: Poverty and Environment Links, Sba-Ecosys-CEDRES (69 p.). Report of the Ministry of the Environment and the Living Environment (MECV).

ONUDI (2009). Information Sub-Region Workshop for French-Speaking West African Countries on the Problems Associated with Gold Panning (34 p.). Synthesis Report.

Ouedraogo, A. (2006). Impact of Artisanal Gold Mining (Gold Panning) on Health and the Environment. Management of Toxic Substances, West Africa Portal. http://www.mediaterre.org/afriqueouest/actu,20061121095625.html

Perraud, A. (1979). Soil Sketch of the Ivory Coast on a 1/2,000,000 Scale. Adiopodoumé: Overseas Office for Scientific and Technical Research (ORSTOM), Center of Adiopodoumé, Côte d'Ivoire.

Predictive Discovery Limited (2014). Large Strong Gold Soil Anomaly in Côte d'Ivoire (23 p.).

Programme des Nations Unies pour l'Environnement (PNUE) (2012). Practical Guide: Reducing the Use of Mercury in the Gold Panning and Artisanal Mining Sector (76 p.).

Roamba, J. (2014). Environmental and Health Risks on Gold Panning Sites in Burkina Faso: Life Cycle of the Main Pollutants and Perceptions of Gold Panning (Case of the Zougnazagmligne Site in the Rural Commune of Bouroum, North-Central Region)(101 p.). Master Thesis in Water and Sanitation, Ouagadougou: International Institute of Water and Environment Engineering, Burkina Faso.

Sirven, J. B. (2006). Detection of Heavy Metals in Soils by Laser Induced Plasma Emission Spectroscopy (252 p.). PhD Thesis, Bordeaux: University Bordeaux 1.

Slater, J. A., Garvey, G., Johnston, C., Haase, J., Heady, B., Kroenung, G., \& Little, J. (2006). The SRTM Data Finishing Process and Products. Photogrammetric Engineering and Remote Sensing, 772, 237-248. https://doi.org/10.14358/PERS.72.3.237

Soro, B. (2011). Agriculture and Raw Materials in Ivory Coast: Cocoa, Coffee, Cotton, Gold, Sugar in Free Fall/The International Financial Crisis Rages. Le Mandat. http://www.koffi.net/koffi/rechercheMultiple/a/43/Withdraw

Soutter, M., Mermoud, A., \& Musy, A. (2007). Water and Soil Engineering Processes and Facilities, Polytechnic Press and French-Speaking Academics (316 p.).

Tagini, B., Gobert, M., Berthoumieux, G., \& Casanova, R. (1972). Geological Map of Ivory Coast. SODEMI. Ivory Coast.

Taylor, H., Appleton, J. D., Lister, R., Smith, B., Chitamweba, D., Mkumbo, O., Machiwa, J. F., Tesha, A. L., \& Beinhoff, C. (2004). Environmental Assessment of Mercury Contamination from the Rwamagasa Artisanal Gold Mining Centre, Geita District, Tanzania. Science of the Total Environment, 343, 111-133.

https://doi.org/10.1016/j.scitotenv.2004.09.042 
Telmer, K. H., \& Veiga, M. M. (2009). World Emissions of Mercury from Artisanal and Small Scale Gold Mining. In N. Pirrone, \& R. P. Mason (Eds.), Mercury Fate and Transport in the Global Atmosphere. Emissions, Measurements and Models (Ch. 6, pp. 131-172). New York: Springer Science + Business Media. https://doi.org/10.1007/978-0-387-93958-2_6

Wandan, E., Koffi, G., Kouadio, K., \& Gomba, D. (2015). Environmental Evaluation of Small-Scale Gold Mining in the Bounkani Region in the Upper East Area of Côte d'Ivoire. International Journal of Environmental Monitoring and Analysis, 3, 265-274. https://doi.org/10.11648/j.ijema.20150305.14

World Organisation Health (WHO) (1994). Quality Guidelines for Drinking Water, Second Edition, Volume 1, Recommendations. Drinking Water-Standards (216 p.).

Yapi, Y. H. A., Dongui, B. K., Trokourey, A., Barima, Y. S. S., Essis, Y., \& Atheba, P. (2014). Assessment of Metallic Pollution of Groundwater and Surface Water in a Gold Mining Environment at Hiré (Côte d'Ivoire). International Journal of Biological Chemistry Science, 8, 1281-1289. https://doi.org/10.4314/ijbcs.v8i3.41 